\title{
PENGARUH PENERAPAN PEER ASSESMENT MELALUI MODEL TEAM ASSISTED INDIVIDUALZATION (TAI) PADA MATERI KELARUTAN DAN HASIL KALI KELARUTAN TERHADAP HASIL BELAJAR SISWA DI SMAN 9 BANJARMASIN
}

\author{
The Effect of Peer Assessment Through Team Assisted Individualization \\ (TAI) On Solubility And Solubility Product To Student's Learning Outcomes \\ In SMAN 9 Banjarmasin
}

Siti Aryani, Herlina Apriani, Okviyoandra Akhyar

Program Studi Pendidikan Kimia Fakultas Keguruan dan Ilmu Pendidikan Universitas Islam Kalimantan Muhammad Arsyad Al Banjari, Banjarmasin *e-mail: sitiaryani07@gmail.com

\begin{abstract}
Abstrak.Hasil belajar materi kelarutan dan hasil kali kelarutan masih rendah disebabkan pembelajaran hanya berpusat pada guru, sehingga siswa hanya pasif mendengarkan. Hal ini mengakibatkan siswa cenderung kurang aktif dan antusias dalam pembelajaran, serta kurang memiliki kemampuan untuk bekerjasama dalam kelompok tujuan dari penelitian ini adalah untuk mengetahui pengaruh peer assessment terhadap hasil belajar siswa melalui model Teams Assited Individuzation. Jenis penelitian ini adalah quasi eksperimen dengan desain posttest-only control group design. Teknik pengambilan sampel dengan Cluster Sampling. Instrumen dalam penelitian ini adalah soal pilihan ganda 10 soal dengan 5 pilihan jawaban yang diujikan pada saat posttets. Pengujian hipotesis menggunakan uji mann whitney u. Hasil analisis data menunjukan bahwa terdapat pengaruh penerapan peer assessment melalui model team assisted individualzation terhadap hasil belajar.
\end{abstract}

Kata Kunci: Hasil Belajar, Kelarutan dan Hasil Kali Kelarutan, Peer Assessment, Team Assisted Individualzation

Abstract. Learing outcomes of solubility and solubility product results are still low due to teacher- only learing, so students just passively listen. This results in students tend to be less active and enthusiastic in learning, and lacking the ability to cooperate in the group of objectives of this study was to determine the effect of peer assessment on student learing outcomes through the Teams Assisted Individualization model. This type of research is quasi-experimental with posttestonly control group design. Sampling teachnique with Cluster Sampling. The instruments in this study were 10 questions multiple choice questions with 4 answer choices tested at the time of posttes. Hypothesis testing using the mann whitney test. The results of data analysis show that there is an effect of implementing peer assessment through the team assisted individualzation model on learning outcomes

Keywords: Learning Outcomes, Peer Assessment, Solubility And Solubility Product, Team Assisted Individualization 


\section{PENDAHULUAN}

Permasalahan yang ada di sekolah SMAN 9 Banjarmasin adalah hasil belajar pada materi kelarutan dan hasil kelarutan masih rendah. Dilihat dari rata - rata nilai ulangan harian tahun ajaran 2016/2017 yang masih dibawah Kriteria Ketuntasan (KKM) yaitu sekitar $70 \%$ nilai siswa masih dibawah KKM. Hal tersebut diketahui melalui wawancara dengan guru kimia SMAN 9 Banjarmasin. Pembelajaran yang umum dimana pembelajaran hanya bepusat pada guru, menyebabkan siswa hanya pasif mendengarkan. Hal ini menyebabkan siswa cenderung kurang aktif dan antusias dalam pembelajaran, serta kurang memiliki kemampuan untuk bekerjasama dalam kelompok.

Berkaitan permasalahan yang ada, maka peneliti mencoba menggunakan model pembelajaran team assisted individualization. Secara tidak langsung siswa akan lebih aktif dan terbentuk kerjasama. Melakukan peer assessment dalam menilai hasil belajar siswa, diharapkan dapat membantu siswa dalam mengembangkan kemampuan bekerjasama, mengkritisi proses dan hasil belajar orang lain dan mendorong siswa untuk memiliki tanggung jawab terhadap proses belajarnya sehingga pelajar dapat mandiri.

Peer Assesment adalah sebuah proses dimana seorang siswa menilai hasil belajar teman atau pelajar lain yang se-level (Topping, Keith. 1998). Peer assessment dapat digunakan untuk membantu pelajar dalam mengembangkan kemampuan bekerjasama, mengkritisi proses dan hasil belajar orang lain (penilian formatif), menerima feedback atau kritik dari orang lain, memberikan pengertian yang mendalam kepada para siswa tentang kriteria yang digunakan untuk menilai proses dan hasil belajar dan untuk penilaian sumatif (Brown, S. dkk. 1994 dalam Zulharman 2007). Menurut Bostock (2000), Wilson (2002) dan Isaacs (1999) menyatakan bahwa Peer Assessment dapat digunakan baik dalam penilaian formatif untuk mendapatkan feedback maupun dalam penilaian sumatif untuk kenaikan kelas (Zulharman, 2007 dalam Amrullah, 2012). Akan tetapi, peer assessment lebih sering dianjurkan untuk digunakan dalam penilaian formatif daripada sumatif (Zulharman, 2007 dalam Amrullah, 2012)

Pembelajaran TAI akan memotivasi siswa saling membantu anggota kelompoknya sehingga tercipta semangat dalam sistem kompetensi dengan lebih mengutamakan peran individu tanpa mengorbankan aspek kooperatif (Islamic, dkk. 2016). Model pembelajaran team assisted individualzation (TAI) menekankan pada pembelajaran secara kelompok, terdapat seorang siswa yang kemampuannya diatas rata - rata ditugaskan untuk menjadi asisten guru untuk membantu siswa lain yang belum memahami materi. Individualisasi dalam pembelajaran TAI didasarkan oleh siswa yang memasuki kelas dengan kemampuan beragam bila kemampuannya tidak diarahkan secara benar maka proses pembelajaran yang dilakukan kurang efektif (Slavin R, 1995 dalam Safitri, dkk. 2017).

Berdasarkan pemaparan latar belakang diatas, penelitian ini bertujuan untuk mengetahui apakah terdapat Pengaruh Penerapan Peer assessment Melalui Model Team Assisted Individualization Pada Materi Kelarutan Dan Hasil Kali Kelarutan Terhadap Hasil Belajar Siswa di SMAN 9 Banjarmasin.

\section{METODE PENELITIAN}

Penelitian dilakukan di SMAN 9 Banjarmasin pada tahun ajaran 2017/2018. Jenis penelitian ini adalah quasi eksperimen dengan desain posttest only control group design. Populasi dalam penelitian ini adalah siswa kelas XI IPA SMAN 9 Banjarmasin. Teknik 
pengambilan sampel pada penelitia ini adalah teknik Cluster Sampling, sampel penelitian ini adalah kelas XI IPA 2 dan kelas XI IPA 3.

Teknik pengumpulan data yang dilakukan dalam penelitian ini adalah tes. Instrumen dalam penelitian ini adalah soal pilihan ganda sebanyak 10 butir soal dengan 5 pilihan jawaban. Validatas isi untuk instrumen soal tes objektif ditetapkan bedasarkan penelitian dan pertimbangan dari penilian, yaitu 1 dosen kimia FKIP UNISKA dan 4 orang guru kimia menggunakan CVR. Sedangkan untuk butir soal pada peneltitian ini berbantuan dengan sofware SPSS tipe v21. Pada penelitian realibitas instrumen, tingkat kesukaran dan daya berbantuan dengan aplikasi anatest. Uji prasyarat yaitu uji normalitas dan homogenitas pada penelitian ini berbantuan sofware SPSS tipe v21. Uji hipotesis juga berbantuan sofware SPSS tipe v21.

\section{HASIL DAN PEMBAHASAN}

Penelitian ini dilakukan terhadap siswa-siswi kelas XI IPA di SMA Negeri 9 Banjarmasin yang belum mempelajari materi kelarutan dan hasil kali kelarutan yang sudah dibekali dengan materi-materi dasar yang menjadi prasyarat objek penelitian in. Materi kelarutan dan hasil kali kelarutan bersifat konseptual dan algoritmik. Materi kelarutan dan hasil kali kelarutan ini tergolong materi yang rumit untuk dipahami, oleh sebab itu diperlukan aktif dan antusias dalam pembelajaran serta bekerjasama dalam kelompok.

Kemampuan bekerjasama dan belajar dengan teman sebaya dalam kelompok sehingga hasil belajar yang didapatkan pun meningkat. Kemampuan bekerjasama dan belajar dengan teman sebaya tersebut diasah melalui model pembelajaran Team Assisted Individualization berbasis pendekatan induktif yang diterapkan dalam setiap kali pertemuan dan dimana penilaian hasil belajar berkelompok melalui metode Peer Assesment.

Penelitian ini diuji cobakan kepada 2 kelas yang menjadi sampel penelitian. Masing-masing dari kelas tersebut yang satu digunakan sebagai kelas eksperimen sedangkan yang lainnya sebagai kelas kontrol. Setiap kelas dilakukan 3 kali pertemuan untuk satu materi pokok. Kedua kelas diberikan alokasi waktu yang sama untuk setiap kali pertemuan yaitu 2 x 45 menit. Team Assisted Individualization berbasis pendekatan induktif yang diterapkan dalam setiap kali pertemuan. Team Assisted Individualization dimana penilaian hasil belajar berkelompok melalui metode Peer Assesment digunakan terhadap kelas eksperimen, sedangkan untuk kelas kontrol menggunakan model Team Assisted Individualization tanpa diperlalukannya penilai melalui metode Peer Assesment. Pada setiap pertemuan siswa kelas eskperimen dan kontrol dibagikan handout sebagai bahan untuk mempelajari materi kelarutan dan hasil kali kelarutan dan menjawab soal berkelompok dan soal latihan sebagai evaluasi belajar individu.

Pada pertemuan pertama sampai pertemuan terakhir setiap siswa dari kelas eksperimen proses belajar melalui model Team Assisted Individualization berbasis pendekatan induktif mempelajari materi kelarutan dan hasil kali kelarutan dan menjawab pertanyaan atau setiap soal yang ada di handout, dalam penskroan berkelompok melalui metode Peer Assesment. Sedangkan untuk kelas kontrol, pada pertemuan pertama sampai terakhir diberikan pembelajaran tentang materi kelarutan dan hasil kali kelarutan dengan model Team Assisted Individualization tanpa diperlalukannya penilai melalui metode Peer Assesment. 
Setelah proses pembelajaran pada pertemuan ke 3 berakhir kedua kelas diberikan posttest pada pertemuan selanjutnya. Post-test ini berupa soal-soal pilihan ganda sebanyak 10 soal. Post-test ini diberikan guna menilai hasil belajar siswa pada kelas eksperimen maupun kelas kontrol apakah ada perbedaan setelah diberi perlakuan. Namun sebelum instrumen diberikan kepada siswa, instrumen tersebut terlebih dahulu dilakukan uji validitas isi kepada validator untuk memastikan apakah instrumen yang akan digunakan layak digunakan atau tidak.

Ringkasan hasil validator isi masing - masing instrument penelitian oleh validator dapat dilihat pada Tabel 1 berikut :

Tabel 1. Hasil rata-rata uji valitas isi

\begin{tabular}{lll}
\hline Instrumen & Rata - rata kevalidan & Keterangan \\
\hline Rpp & $100 \%$ & Valid \\
Soal post - test & $100 \%$ & Valid \\
Angket KBK & $100 \%$ & Valid \\
\hline
\end{tabular}

Instrument yang diuji cobakan berupa soal pilihan ganda 10 soal dengan hasil uji validitas butir soal $100 \%$ soal valid. Uji reliabilitas pada penelitian ini menggunakan anatest, instrumen soal pada penelitian ini mempunyai skor koefisien realibitas tes sebesar 0,77 . Nilai itu menunjukkan bahwa tingkat reliabilitasnya termasuk kedalam golongan tingkat realibitas tinggi sehingga layak untuk digunakan. Perhitungan uji tingkat kesukaran pada 10 butir soal menggunakan anates terdapat 1 soal tergolong sangat mudah, 5 soal tergolong mudah dan 4 soal tergolong sedang. Berdasarakn perhitungan daya pembeda instrumen soal menggunakan anates terdapat 6 soal tergolong baik dan 4 soal tergolong baik sekali.

Guna mengetahui uji hipotesis yang cocok digunakan maka dilakukan uji prasyarat terlebih dahulu. Uji prayarat yang dilakukan berupa uji homogenitas dan uji normalitas. Berdasarkan uji normalitas didapatkan hasil bahwa uji normalitas 0,035 sehingga dapat dikatakan data tidak terdistribusi normal sebab uji normalitas dikatakan normal jika nilai sig > 0,05 (Sugiyono, 2010). Berdasarkan uji homogenitas didapatkan hasil bahwa nilai sig 0,106 yang berarti varians kedua sampel ini dikatakan homogen karena signya $>0,05$ (Sarwono, 2012). Dilihat dari data pada penelitian ini data dikatakan tidak normal tetapi homogen maka untuk uji hipotesisnya menggunakan uji non-parametrik yaitu uji Mann Whitney U.

Bedasarkan hasil uji hipotesis menggunakan uji Mann Whitney U diketahui sig < 0,05 yang bearti $\mathrm{H}_{0}$ ditolak, $\mathrm{H}_{1}$ diterima (Arikunto, 2009). Data hipotesis ini menunjukkan bahwa terdapat pengaruh penerapan peer assessment melalui model team assisted individualization terhadap hasil belajar siswa pada materi kelarutan dan hasil kali kelarutan. Penerapan peer assessment melalui model team assisted individualization terbukti berpengaruh positif terhadap hasil belajar dan bekemampuan untuk bekerjasama. Melalui kegiatan perlibatan peserta didik dalam proses penilaian, peserta didik mampu mengembangkan kerjasama, mengkritisi proses dari hasil belajar orang lain, menerima feedback atau kritik dari orang lain (Zulharman, 2007). Proses mengkritisi inilah siswa dituntut untuk menguasai meteri. 
Tujuan team assisted individualization (TAI) adalah untuk meminimalisasi pengajaran individual yang tebukti kurang efektif, selain juga ditujukan untuk meningkatkan pengetahuan, kemampuan seta motivasi siswa dengan belajar kelompok. Model pembelajaran team assisted indiviualization (TAI) menekankan pada pembelajaran secara kelompok, terdapat seorang siswa yang kemampuannya diatas rata -rata ditugaskan untuk menjadi asisten guru untuk membantu siswa lain yang belum memahami materi. Individualisasi dalam pembelajaran TAI didasarkan oleh siswa yang memasuki kelas dengan kemampuan beragam bila kemampuannya tidak diarahkan secara benar maka proses pembelajaran yang dilakukan kurang efektif (Slavin R, 1995 dalam Safitri N. F., Sukro., Suhartono, 2017). Ketika proses pembelajaran melalui Team Assited Individualization sangat membantu siswa aktif, mandiri dalam belajar dan terbentuknya kerjasama dalam kelompik Sesuai dengan yang dikemukakan manfaat dari Team assisted Individualization Slavin (1984) dalam Lestari (2005) adalah meminimalisai keterlibatan guru dalam pemeriksaan dan pengelolaan rutin, melibatkan guru untuk mengajar kelompok - kelompok kecil yang heterogen, memudahkan siswa untuk melaksanakannya karena teknik operasional yang cukup sederhana, memotivasi siswa untuk mempelajari materi - materi yang diberikan dengan cepat dan akurat tanpa jalan pintas, memungkinkan siswa untuk bekerja dengan siswa - siswa lain yang berbeda sehingga tercipta sikap positif diantara mereka.

Telibatnya siswa dalam penilaian, siswa menjadi tahu kriteria penilian mereka sehinga siswa akan cenderung melakukan sesuai dengan kriteria penilian. Siswa dituntut untuk turut serta dalam proses pembelajaran secara tidak langsung mereka menjadi aktif dalam pembelajaran dan suasana belajar lebih menyenangkan sehingga hasil belajar lebih optimal. Suasana belajar seperti ini juga tergambar dalam pembelajaran dengan penilaian peer assessment melalui model Team Assisted Individualization. Seperti yang dikemukan menurut White( 2009) dalam Kurniawan (2016) keuntungan peer assessment diantaranya membantu siswa untuk menjadi lebih otonom, bertanggung jawab, dan terlibat, mendorong siswa untuk secara kritis menganalisis pekerjaan yang dilakukan oleh orang lain, bukan hanya melihat tanda, membantu memperjelas criteria penilaian, memberikan siswa lebih luas umpan balik, lebih sejajar situasi karir mungkin dimana pengambilan keputusan yang dibuat oleh kelompok, mengurai beban pada dosen, beberapa kelompok dapat dijalankan sekaligus karena tidak semua kelompok memerlukan kehadiran guru. Hal ini membuktikan bahwa penerapan peer assissment melalui model pembelajaran team assisted individualization (TAI) baik digunakan dalam proses pembelajaran terutama untuk meningkatkan hasil belajar.

\section{PENUTUP}

Berdasarkan hasil uji hipotesis menggunakan uji Man Whitney U dengan sig < 0,005 maka dapat simpulkan bahwa terdapat pengaruh Penerapan Peer Assesment melalui model Team Assisted individualization pada materi kelarutan dan hasil kali kelarutan. Berdasarkan hasil penelitian maka peneliti dapat mengemukakan beberapa saran yaitu :

1. Penerapan peer assessment melalui melalui model Team Assisted individualization yang telah diterapkan pada siswa kelas XI IPA 9 Banjarmasin berpengaruh terhadap hasil belajar siswa sehingga diharapkan menjadi pembelajaran alternatif dalam pembelajaran kimia 
Dalton : Jurnal Pendidikan Kimia dan Ilmu Kimia, Volume 1 Nomor 2, November 2018

2. Bagi guru maupun pihak lain yang akan menerapkan peer assessment melalui melalui model Team Assisted individualization dalam kegiatan pembelajaran, sebaiknya mengatur waktu dengan tepat karena pembelajaran ini memerlukan waktu lebih lama.

3. Peneliti selanjutnya hendaknya meneliti dengan materi yang berbeda dan lebih banyak referensi lagi.

\section{DAFTAR RUJUKAN}

Amrullah, F. (2012). Penerapan Peer Assessment Dalam Kegiatan Praktikum Rangkaian Logika Untuk Menilai Kinerja Siswa Pada Kompetensi Menerapkan Rangkaian Elektronika Digital Di Smk Negeri 12 Bandung. Skiripsi. Bandung: Universitas Pendidikan Indonesia

Arikunto, S. (2009). Prosedur Penelitian Suatu Pendekatan Praktik. Edisi Revisi 6. Jakarta : Rineka Cipta

Islamic.A.R., Sukardjo.J.S., Dan Nurhayati. N. D. (2016). Penerapan Metode Pembelajaran Team Assisted Individualization (Tai) Dilengkapi Media Handout Untuk Peningkatkan Prestasi Belajar Dan Interaksi Sosial Siswa Pada Materi Pokok Tata Nama Senyawa Kimia Dan Persamaan Reaksi Kimia Kelas X2 Sma Negeri Gondangrejo Karanganyar Tahun Pelajaran 2013/2014. Jurnal Pendidikan Kimia, 5(2), 68-74.

Kurniawan, D. (2016). Penggunaan assessment for learing (AFL) melalui peer assessment untuk meningkatkan mathematical problem solving. Jurnal Penelitian dan Pengajaran Matermatika, 2(2), 87-98

Lestari, P. (2015). Penerapan model pembelajaran team assisted individualization (TAI) untuk meningkatkan penalaran siswa pada materi sistem pernapasan do M.A AlMuayyad Iii Tegowanu Grobogan. Skripsi. Semarang. Fakultas Ilmu Tarbiyah dan Keguruan Universitas Islam Negeri Walisongo

Safitri N. F., Sukro., Suhartono. (2017). Pengaruh Model Pembelajaran Kooperatif Tipe Team Assisted Individualization (Tai) Terhadap Hasil Belajar Siswa Pada Materi Kesetimbangan Ion Dan Ph Larutan Garam Kelas Xi Di Sman 54 Jakarta. Jurnal Riset Pendidikan Kimia, 7(1).

Sarwono, J. 2012. IBM SPSS “Advancees Statistic": Prosedur-Prosedur Generalisasi dan Perluasan General Linear Model (GLM). Yogyakarta : ANDI

Sugiyono. 2010. Metode penelitian Kuantitatif Kualitatif \& RND. Bandung: Alfabeta

Topping, K. (1998). "Peer Assessment between Students in Colleges and Universities. Review of Educational Research. Jurnal Article, 68(3), 249-276

Zulharman, 2007. Self dan peer assessment sebagai penilaian formatif dan sumatif. Skripsi sebagai penilaian formatif dan sumatif. Skripsi Yogyakarta: Fakultas Kedokteran Universitas Gadjah Mada. 